\title{
Responsabilidade social empresariais ações em tempos de pandemia
}

\author{
Corporate social responsibility actions in times of pandemic \\ Acciones de responsabilidad social empresarial en tiempos de pandemia
}

Recebido: 02/07/2021 | Revisado: 06/07/2021 | Aceito: 09/07/2021 | Publicado: 21/07/2021

\author{
Andréia Ferreira Martins \\ ORCID: https://orcid.org/0000-0002-9907-0855 \\ Universidade Estadual Paulista, Brasil \\ E-mail: psicologa.andreiamartins@gmail.com \\ Osvaldo Júlio da Silva Filho \\ ORCID: https://orcid.org/0000-0003-1909-0483 \\ Universidade Estadual Paulista, Brasil \\ E-mail: osvaldo.julio@ hotmail.com \\ Téucle Mannarelli Filho \\ ORCID: https://orcid.org/0000-0003-0040-0517 \\ Universidade Estadual Paulista, Brasil \\ E-mail: teucle@terra.com.br
}

\begin{abstract}
Resumo
A pandemia da Covid-19 vem desde 2020 causando impactos relevantes em todo mundo, não só nos hábitos das pessoas, mas principalmente nas empresas; que vem tomando medidas na prevenção da contaminação de seus colaboradores, clientes e fornecedores. Neste contexto o presente artigo tem por objetivo compreender e investigar, como as empresas se mobilizaram diante de um cenário adverso de crise e analisar as ações e medidas adotadas para o enfrentamento, frente as orientações da OMS e dos principais guias de orientações de responsabilidade social empresarial-RSE. A investigação realiza uma contextualização e revisão teórica da Responsabilidade Social Empresarial no contexto da pandemia e das ações empresariais que foram implementadas pelas empresas pesquisadas. Trata-se de uma pesquisa exploratória qualitativa, realizada em três empresas de diferentes setores empresariais, escolhidas por conveniência; sendo os dados coletados por meio de questionários semiestruturados, com a elaboração de uma análise de conteúdo; posteriormente apresentados sumarizados em tabelas individualizadas. Os resultados se apresentam basicamente na confirmação de que as empresas pesquisadas, somente adotaram as medidas básicas das recomendações da OMS: uso obrigatório de mascaras, distanciamento social quando possível e disponibilização de álcool gel. Não se identifica ações efetivas de comunicação e responsabilidade social empresarial, por parte das empresas, buscando mitigar os riscos da Covid-19, junto a seus funcionários, clientes e fornecedores. As restrições do estudo se relacionam com a escolha por conveniência das empresas, e a escolha do entrevistado nas empresas, que pode distorcer os dados coletados; ainda que novas linhas de pesquisa emergem, em razão que as empresas continuam imersas na pandemia, na busca de melhor compreender os mecanismos de comunicação adotados pelas empresas e as falhas de comunicação incorridas pelas empresas. Finalmente que o objetivo proposto na investigação foi plenamente atingido.
\end{abstract}

Palavras-chave: Comunicação empresarial; Responsabilidade social; Covid-19; Pandemia.

\begin{abstract}
The Covid-19 pandemic has been causing relevant impacts around the world since 2020, not only in people's habits, but mainly in companies; which has been taking measures to prevent contamination of its employees, customers and suppliers. In this context, this article aims to understand and investigate how companies mobilized in the face of an adverse crisis scenario and to analyze the actions and measures taken to cope with the guidelines of the WHO and the main guidelines for corporate social responsibility guidelines -CSR. The investigation performs a contextualization and theoretical review of Corporate Social Responsibility in the context of the pandemic and the corporate actions that were implemented by the surveyed companies. It is a qualitative exploratory research, carried out in three companies from different business sectors, chosen for convenience; being the data collected through semi-structured questionnaires, with the elaboration of a content analysis; later presented summarized in individual tables. The results are basically presented in the confirmation that the companies surveyed only adopted the basic measures of the WHO recommendations: mandatory use of masks, social distancing when possible and availability of alcohol gel. Effective communication and corporate social responsibility actions are not identified by companies, seeking to mitigate the risks of invite-19, with its employees, customers and suppliers. The study's restrictions are related to the choice for convenience of the companies, and the choice of the respondent in the companies, which can distort the data collected; even though new lines of research are emerging, as companies continue to be immersed in the pandemic, in the quest to better understand the communication mechanisms adopted by companies and the failures of communication incurred by companies. Finally that the objective proposed in the investigation was fully achieved.
\end{abstract}


Keywords: Business communication; Social responsibility; Covid-19; Pandemic.

\section{Resumen}

La pandemia de Covid-19 viene provocando impactos relevantes en todo el mundo desde 2020, no solo en los hábitos de las personas, sino principalmente en las empresas; que viene tomando medidas para evitar la contaminación de sus empleados, clientes y proveedores. En este contexto, este artículo tiene como objetivo comprender e investigar cómo las empresas se movilizaron ante un escenario de crisis adverso y analizar las acciones y medidas tomadas para hacer frente a los lineamientos de la OMS y los principales lineamientos de la RSE de responsabilidad social empresarial. La investigación realiza una contextualización y revisión teórica de la Responsabilidad Social Empresarial en el contexto de la pandemia y las acciones corporativas que fueron implementadas por las empresas encuestadas. Se trata de una investigación cualitativa exploratoria, realizada en tres empresas de diferentes sectores empresariales, elegidas por conveniencia; siendo los datos recogidos a través de cuestionarios semiestructurados, con la elaboración de un análisis de contenido; posteriormente presentado resumido en tablas individuales. Los resultados se presentan básicamente en la confirmación de que las empresas encuestadas solo adoptaron las medidas básicas de las recomendaciones de la OMS: uso obligatorio de mascarillas, distanciamiento social cuando sea posible y disponibilidad de gel de alcohol. Las acciones efectivas de comunicación y responsabilidad social corporativa no son identificadas por las empresas, buscando mitigar los riesgos de invite-19, con sus empleados, clientes y proveedores. Las restricciones del estudio están relacionadas con la elección por conveniencia de las empresas y la elección del encuestado en las empresas, lo que puede distorsionar los datos recopilados; a pesar de que surgen nuevas líneas de investigación, a medida que las empresas continúan inmersas en la pandemia, en la búsqueda de comprender mejor los mecanismos de comunicación adoptados por las empresas y las fallas de comunicación en las que incurren las empresas. Finalmente que el objetivo propuesto en la investigación se logró plenamente.

Palabras-clave: comunicación empresarial; Responsabilidad social; Covid-19; Pandemia.

\section{Introdução}

Apesar de já anunciada desde o fim de 2019 a presença de uma infecção causada por um vírus principalmente na província de Wuhan na China, e que posteriormente se alastrou pela Ásia e Europa durante o mês de janeiro, foi em 25 de fevereiro que se registrou oficialmente no Brasil, o primeiro caso diagnosticado de Covid-19. Era uma terça feira de carnaval e milhões de pessoas celebravam a data de norte a sul do país. Já no final de janeiro a Organização Mundial da Saúde (OMS) considerava o surto do Corona vírus uma Emergência de Saúde Pública de importância internacional, e em 11 de março, o diretor-geral da OMS Tedros Adhanon fez o anuncio em Genebra, de que a doença causada pelo novo coronavirus se caracterizava uma pandemia. Na ocasião conforme dados da OMS, existiam mais de 118 mil casos em 114 países com um número de 4,2 óbitos. No Brasil nesta data, o ministério da saúde contabilizava 52 casos confirmados em 08 estados da federação, sem nenhum óbito, o que só veio a ocorrer oficialmente em dia 12 de março em São Paulo (OPAS, 2020).

A partir desta data, assistimos diariamente o número de casos e óbitos seguirem uma curva ascendente completando no final de setembro de 2020 com números próximos a 4,8 milhões de casos e mais de 142 mil óbitos, impactando diretamente a vida das pessoas no sentido lato da palavra, seus comportamentos, e com fortes impactos políticos, econômicos e sociais, o que leva alguns historiadores a supor que a pandemia é o marco que inicia o século XXI.

No Brasil, com a pandemia se descortina sérios problemas estruturais para o enfrentamento de um evento de tal magnitude frente as necessidades com os cuidados básicos que a situação exigia. Se de um lado havia a garantia de um Sistema Único de Saúde - SUS fruto da constituição de 1988, este mesmo sistema apresentou deficiências básicas, que iam da ausência de equipamentos, material, medicamentos, recursos humanos e estrutura de terapia intensiva para casos mais graves, até materiais básicos de proteção individual aos profissionais e para limpeza e higienização Da mesma forma em quanto a OMS advertia com os cuidados básicos para contenção da pandemia como: lavagem das mãos, higienização de utensílios, uso de máscaras e distanciamento social, nos deparamos com a realidade de um país onde $16 \%$ da população não tem acesso a água tratada e menos de $50 \%$ dos esgotos recebem tratamento, conforme dados do SNIS- Sistema Nacional de Informações Sobre Saneamento em 2018 (SNIS, 2018). Apesar do vírus ter o caráter de universalização da doença, sabemos que os mais impactados serão os mais penalizados e expostos a contaminação e sem muitas alternativas para realização do devido 
tratamento. Como nós já nos referimos, a pandemia escancarou as fragilidades e desigualdades sociais no qual nosso país está imerso.

Neste cenário, e na contramão das bases dos neoliberais da exaltação do indivíduo, vimos nascer um processo de solidariedade com destaque ao setor empresarial, que contrariando os preceitos do capitalismo de substituir a função do estado, saiu em apoio através de doações e mobilizações à sociedade, seja através do suporte a estrutura pública, cuidados e prevenção a empregados e a sociedade de forma geral.

Portanto este artigo busca compreender como as empresas se mobilizaram diante de um cenário adverso de crise e analisar as ações e medidas adotadas para o enfrentamento, frente as orientações da OMS e dos principais guias de orientações de responsabilidade social empresarial -RSE.

\section{Metodologia}

O presente estudo parte de uma revisão da literatura sobre a responsabilidade social empresarial. Utiliza-se da literatura clássica dos temas pesquisados e das publicações disponíveis nos portais de periódicos científicos: Capes, "Scopus", Google Acadêmico e "web of sciencie" e nos sites de órgãos governamentais e das empresas pesquisas; em que se busca identificar todo conhecimento cientifico que já foi produzido sobre o tema, identificando os aspectos relevantes para a presente pesquisa.

A seleção das empresas foi não probabilística, intencional, pela facilidade de acesso aos dados e informações, com empresas de diferentes setores econômicos, em diferentes regiões geográficas, com diferentes tamanhos; entretanto todas as empresas foram diretamente impactadas diretamente pela Covid-19. Adotou-se uma abordagem exploratória e qualitativa.

Estas empresas selecionadas apresentam características diferentes; sendo: a) Um Curtume, que já possui mais trinta anos de funcionamento, uma empresa familiar com gestão dos proprietários e 122 funcionários; b) Uma cooperativa de credito, com gestão profissional, com aproximadamente 17.000 cooperados e atuação no estado de São Paulo, com 16 agencias nas cidades: Osvaldo Cruz, Presidente Epitácio, Adamantina, Panorama, Garça, Araçatuba, Santa Cruz do Rio Pardo, Pirapozinho, Presidente Prudente, Dracena, Campinas, São Paulo, Rio Claro, Araras, Santa Gertrudes, Lucélia, e ainda três escritório de negócios nas cidades: Regente Feijó, Osasco e Mirante do Paranapanema; ainda possui 189 funcionários; c) Uma Usina de Tratamento de Madeira, localizada no estado do Mato Grosso do Sul, com 12 funcionários, verticalizada que produz a madeira, realiza o tratamento químico, realiza a comercialização e entrega para seus clientes, empresa familiar com gestão de seus três proprietários.

Para assegurar a qualidade das informações, adotou-se o procedimento da identificação do gestor da empresa previamente selecionada; que fosse capaz de compreender os conceitos abordados na pesquisa e ainda detivesse as informações requeridas; sendo que foram entregues termos de responsabilidade devidamente assinados, nos quais os pesquisadores se comprometem com todas as questões éticas na condução da pesquisa e na utilização dos dados obtidos. Ainda que as entrevistas foram realizadas presencialmente, no período de 01 a 10 de outubro de 2020.

Segundo Godoy, (1995) uma pesquisa qualitativa não parte de hipótese previamente estabelecida, sendo que se preocupa em obter os dados e ou as evidencias que neguem ou confirme suposições preliminares; parte de questões e focos de interesses amplos e mais específicos que, no transcorrer da investigação, ajudam a construir, a partir dos dados, um processo que emerge de baixo para cima.

A pesquisa qualitativa, segundo Silva, Gobbi e Simão, (2005) não se apresenta como um esquema rígido de utilização, e o pesquisador pode e deve utilizar a flexibilidade, entretanto, deve permanecer o compromisso de apresentar um quando de nitidez teórica e de postura metodológica; ainda que o investigador precise conseguir captar o ponto de vista dos participantes, realizando um processo continuo de validação. 
Ainda segundo Câmara, (2013), a estrutura metodológica precisa ser rigorosamente planejada e ater-se aos aspectos éticos do pesquisador, e, finalmente a obtenção dos dados requer um redobrado cuidado com relação às opiniões dos respondentes e da organização. O caráter exploratório, segundo Dalfovo, Lana, e Silveira, (2008), caracteriza-se quando existem poucas informações sobre o objeto pesquisado.

As entrevistas realizadas tiveram caráter informal e foram conduzidas pelos pesquisadores, pessoalmente ou por meio de e-mail, com um gestor de cada uma das empresas pesquisadas; acautelando-se que este entrevistado tivesse o entendimento dos temas abordados na pesquisa. As entrevistas mesmo informais, seguiram um roteiro básico por meio de questionários semiestruturados, com perguntas objetivas, e ao mesmo tempo permitindo aos entrevistados abordar aspectos que julgassem relevantes; sendo que o referencial teórico se baseia em Sampieri, Collado, e Lucio, (2003); Cooper e Schindler, (2001); e ainda, Creswel, (2014).

Os dados coletados na pesquisa qualitativa seguirão, rigorosamente, a referência teórica de uma Análise de Conteúdo, com os preceitos teóricos de (Godoy, 1995, Bardin, 2011 e Câmara, 2013). Esta análise será elaborada nas etapas recomendadas por Bardin, (2011), sendo uma primeira etapa para elaboração da Pré Análise dos dados e uma categorização dos dados obtidos, sequencialmente uma segunda etapa de Exploração do Material para a codificação dos dados, e, finalmente uma terceira etapa com o Tratamento e os Resultados, com a inferência e interpretação dos dados coletados e obtidos.

\section{Revisão Bibliográfica}

\subsection{Responsabilidade Social Empresarial}

Conforme a norma ISO 2600 de 2010, a responsabilidade social se caracteriza pelo desejo de uma organização de incorporar em sua gestão aspectos socioambientais, assumindo a responsabilidade pelos impactos de suas decisões e impactos na sociedade e no meio ambiente. Para tanto é necessário para que a empresa incorpore tal pratica a adoção de um comportamento transparente e ético que contribua para o desenvolvimento sustentável considerando os interesses das partes interessadas (ISO, 2010)

Apesar das caraterísticas constante na ISO ser relativamente recente, o histórico da responsabilidade social vem sendo forjado a bastante tempo. Savitz, (2007), refere que as primeiras manifestações dizem respeito as fundações caritativas com fins filantrópicos, na década de 1920, a exemplo de Rockefeller - Standard Oil Company, Henry Ford - Ford Motor Company e Andrew Carnagie - Carnegie Steel Company, como forma de resgatar a reputação das de seus negócios, visto que à época haviam questionamentos éticos sobre a forma de com a qual os mesmos construíram suas fortunas.

[...] esses grandes próceres decidiram, anos depois, restituir à sociedade parte da riqueza que mor meio dela, conseguiram acumular. Com esse intuito, construíram universidades, hospitais, museus, bibliotecas, escolas, igrejas que até hoje são fatores importantes para melhorar a qualidade de vida (Savitz, 2007 p.50).

Com o crescente desenvolvimento industrial, muitas empresas começaram a criar no entorno de suas instalações fabris uma serie de equipamentos como conjuntos habitacionais, escolas, igrejas, equipamentos de lazer, alguns como no caso de Hershey pelo idealismo de criação de um mundo melhor, já outros como forma de exercer maior controle sobre a vida de seus empregados. A partir da década de 1930, o conceito se deslocou para o âmbito dos direitos trabalhistas fruto da organização sindical que pressionava por melhores condições de trabalho (Savitz, 2007)

Esse foi um período de alteração do processo produtivo que estava intimamente relacionado com a evolução tecnológica e a aplicação da ciência nas organizações o que contribuíram na discussão da responsabilidade social tendo como foco principal as questões relacionadas as questões trabalhistas (Tenório, 2007 p.15) 
Nesse período, não havia por parte da classe empresarial nenhuma preocupação com as consequências geradas pelos seus negócios, a responsabilidade social se efetivava por meio da filantropia de forma assistencialista, sem em nenhum momento se realizar uma análise dos impactos de seus negócios na sociedade. Essa perspectiva se alterou a partir da década de 1960 quando houve uma maior conscientização da sociedade sobre os impactos causados pelas indústrias, com foco inicial na questão ambiental. A organização da sociedade e o surgimento de forma mais ampla dos movimentos sociais organizados nas décadas seguintes, trouxeram à tona outros temas como: os direitos civis, direitos das mulheres, liberdade de gênero, direitos dos consumidores, trabalho infantil ou escravo, cuidados ambientais, entre outros (Tenório, 2007 p. 16-18).

A busca pela sua sustentabilidade, tem sido determinante para que a empresa adote posturas distintas daquelas praticadas no século XIX e do início do sec. XX. A sociedade está mais consciente, principalmente os jovens que já nasceram em um mundo totalmente conectado, com valores distintos das gerações anteriores. Com a informação na palma da mão, lhes permitem que em tempo real sejam testemunha de algum dano ambiental praticado em qualquer lugar do planeta, ou de algum desrespeito aos direitos fundamentais, e a partir do fato mobilizar milhões de pessoas em todo planeta impactando diretamente na marca ou na reputação de quem efetivamente gerou o referido dano. Por outro lado, o crescimento do conceito neoliberal, tem reduzido significativamente o poder do estado - Estado mínimo, migrando o poder do setor público para as grandes corporações. Com isso cresceu a pressão sobre as empresas de suas responsabilidades sociais e ambientais como nunca visto em outros tempos (Tenório, 2007 p. 18-26).

Quando o professor e filosofo Edward Freeman forjou o termo stakeholder em 1984, definindo como tal, as partes interessadas que afetam e são afetadas pelas corporações, a dimensão da responsabilidade social toma outra significância e importância. Neste conceito as corporações deveriam levar em consideração não apenas as os interesses dos shareholders acionistas, mas os interesses dos empregados, fornecedores, clientes, comunidades, investidores, governos, órgãos reguladores, sociedade civil, imprensa..., ou seja, todos que afetam e podem ser afetados pelas suas atividades, evidenciando a necessidade das empresas de assumirem uma maior responsabilidade (Savitz, 2007 p. 50-68).

Fazer negócios nesse novo mundo - mais livre, mais independente, mais conectado e apinhado de stakeholders vociferantes e poderosos - exige alto grau de responsabilidade. Não se pode fingir que está operando no vácuo. Ao contrário, as empresas hoje atuam como que num bairro superpopuloso, no qual todos conhecem seu negócio, opinam sobre ele e tentam por todos os meios mudar seu comportamento. Denominemos esse período de Era da Responsabilidade, um novo tempo para as empresas, no qual corresponder as demandas da sustentabilidade é necessidade inequívoca, não apenas uma questão de escolha (Savitz, 2007 p. 68).

Apesar dos pressupostos de Friedman, (1984), que argumentava que o objetivo central da empresa é a maximização do lucro, portanto se a empresa realizar sua missão de suprir a demanda da sociedade já estaria cumprindo a sua função social, o mercado tem observado que as ações de responsabilidade social são efetivas para os negócios minimizando riscos, melhorando a imagem, atendendo as expectativas dos stakeholders gerando sustentabilidade em toda a cadeia produtiva. Esse argumento forjado por Friedman, não mais representa o pensamento das empresas na contemporaneidade (Silva Filho, 2018).

Por fim, é importante destacar a importância da teoria dos stakeholders no suporte para a responsabilidade social corporativa. Mesmo que o desenvolvimento tenha sido a gestão estratégica empresarial, mas os conceitos amalgamados na mesma, lança luz sob a responsabilidade que as empresas devem ter com suas partes interessadas. Isto não é mais uma opção, mas uma condição para sobrevivência empresarial. (Rodrigues, 2005 p. 32).

\subsection{Formas de Atuação Social}

Na discussão sobre o contexto, o termo responsabilidade social empresarial traz em seu conceito diversas dimensões, face a seu desenvolvimento ao longo dos anos. Tenório, (2007) destaca três formas básicas de atuação social das empresas: a) 
Filantropia empresarial; b) Cidadania empresarial; c) Responsabilidade social corporativa, que seguem uma forma evolutiva do termo, mas que ainda coexistem na atualidade.

A filantropia empresarial, tem como suas bases a atitude altruísta e desprendida, relacionada a virtude cristã. Schommer, (2000) afirma que a filantropia empresarial tem como característica o caráter assistencialista, caridosa e temporária. A filantropia por vezes concentra-se na destinação de verbas para fins específicos. Essa característica histórica associada a filantropia, como o assistencialismo e caridade carregam consigo uma conotação negativa, visto que não geraram transformações sociais e econômicas profundas, estavam mais ligadas à vontade pessoal do filantropo, fora das estratégias e políticas das empresas (Borger, 2013).

Quanto à cidadania empresarial, já se percebe um maior envolvimento da empresa no contexto social, seja através de apoio a projetos e ações sociais externos, pela doação de mão de obra nos moldes de voluntariado empresarial ou como Schommer (2000) refere ser a cidadania empresarial a participação ativa da empresa em suas relações com as cidades e comunidades com as quais dividem o mesmo território.

Por fim a responsabilidade social corporativa ou empresarial, é entendido conforme Tenório, (2007), como." compromisso da empresa com a sociedade na busca da melhoria da qualidade de vida da comunidade". Para Guédez, (2014), a RSE, é parte da estratégia empresarial para retorno positivo de imagem, reputação e posicionamento, visto que a forma como ela é percebida pela sociedade é determinante para seu desenvolvimento. Sólio, (2013) por sua vez considera que as empresas devem considerar seus impactos sociais e ambientais para evitar que pressão de grupos sociais e consumidores maculem sua imagem e reputação impactando diretamente em seu lucro.

Para o Instituto Ethos o conceito de responsabilidade social corporativa ou empresarial, está relacionado a relação que as empresas estabelecem com todos os seus públicos no curto e longo prazo. Definição essa que é compartilhada por outras organizações mundiais como: IFC - International Finance Corporation; BSR - Business for Social Responsability, CSR Europe - Corporate Social Responsability (Ethos, 2012).

Este posicionamento baseado na relação estabelecida entre empresas e seus públicos, tem sua base conceitual a teoria dos stakeholders, imputando a empresa suas responsabilidades perante seus diversos públicos e possibilitando à incorporação em seu planejamento estratégico das questões sociais minimizando riscos ao negócio, imagem e reputação. Entretanto, ao assumir a Responsabilidade Social Empresarial, as empresas impactam diretamente a sociedade em seu entorno, seja através de prática e gestão responsáveis, seja através do Investimento Social Privado. O GIFE. Grupo de instituto, fundações e empresas, define o investimento social privado - ISP como: [...]o repasse voluntario e sistemático de recursos privados, de forma planejada e monitorada para projetos sociais de interesse público (Gife, 2007).

A cada dois anos o GIFE, realiza um censo com seus associados analisando a estrutura forma de atuação e estratégias das empresas, institutos e fundações empresariais que destinam recursos privados para projetos de finalidades públicas. $\mathrm{Na}$ última edição do censo, realizado em 2018 com a participação de 133 dos 184 associados, verificou-se que os valores investidos em 2018, chegavam a R \$3,25 bilhões de reais. Relativizando esses valores, o orçamento empenhado do ministério do meio ambiente naquele ano contabilizava $R$ \$ 1,1 bilhões, o do ministério da cultura $R$ \$ 1,5 bilhões e o ministério do esporte com R $\$ 2,5$ bilhões (Gife, 2018).

Esses valores demonstram a magnitude que o investimento social privado exerce junto a sociedade, fruto da incorporação da responsabilidade social empresarial como estratégia empresarial, independente dos fatores motivacionais.

Com o advento da pandemia e diante da incapacidade do poder público na agilidade para condução do tema, as empresas, fundações institutos e algumas pessoas físicas, protagonizaram um movimento, que demonstra um certo deslocamento do poder e de eficácia em relação ao poder público, mobilizando o valor de 7,44 bilhões até maio de 2021, com destaque ao período inicial da pandemia, onde essas organizações e em um período compreendido entre 31 de março e 27 de 
setembro, arrecadaram $\mathrm{R} \$ 6,34$ bilhões para o enfrentamento a pandemia. Esses recursos foram prioritariamente destinados a saúde $(73 \%)$ assistência social $(21 \%)$, educação (4\%) e geração de renda (2\%) conforme publicado no site da ABCRAssociação Brasileira de Captadores de Recursos (ABCR, 2021).

Um exemplo semelhante havia ocorrido em 2005, quando do evento do furacão Katrina, nos Estados Unidos. Enquanto o governo americano se atrapalhou no socorro às vítimas, grandes empresas se reuniram e não só garantiram a continuidade de suas operações, como foram mais eficazes que o poder público no atendimento as pessoas desabrigadas (Savitz, 2007 p. 61).

Guardada as devidas proporções isso tem demonstrado que com o estabelecimento do estado mínimo, dentro do modelo neoliberal, cada vez mais as empresas serão cobradas pela sociedade para apoiar problemas que em um passado eram competência exclusiva dos governos. Dessa forma o mundo corporativo tem cada vez mais assumido o protagonismo de algumas funções, seja por impactos gerados pelas suas operações, ou para atender as expectativas de seus stakeholders com relação a sua responsabilidade social, o que acarreta em maior sustentabilidade para o negócio.

\subsection{Indicadores Ethos de Responsabilidade social}

O Instituto Ethos de Empresas e Responsabilidade Social surge em 1998, como uma Organização da Sociedade Civil de Interesse Público. Seus criadores são um grupo de empresários e executivos da iniciativa privada cujo objetivo é a mobilização de uma nova cultura de responsabilidade social empresarial tornando as empresas parte atuante na sociedade não só como condição de marketing ou visão econômica futura, mas como agente da sociedade com interesses da sociedade. Mudando o comportamento único de capitalismo para o comportamento de responsabilidade social, orientados por indicadores, critérios e ética. Contribuindo para o desenvolvimento social e sustentável onde a economia gera um ciclo de beneficiamento tanto da empresa como da comunidade que se beneficia ou é beneficiada por esta empresa direta ou indiretamente tendo como princípio de responsabilidade por todas as condições e pessoas que são afetadas por suas atividades. Para uma economia mais justa e de responsabilidade social diante das condições advindas da empresa ou pela empresa para os que recebem benefícios empregos ou indiretamente proventos (ETHOS, 2019).

Acredita-se que empresas conscientes vão refletir em uma sociedade cada vez mais preparada e atuante no crescimento econômico, neste sentido o Instituto Ethos criou um Manual de Critérios Essenciais de Responsabilidade Social e Empresarial, tão particularmente análogo aos almejos constitucionais, morais e até religiosos com qual convivemos e ignoramos perante nosso próprio crescimento egoísta e vil. O Instituto tem como condição o respeito à sociedade e integridade física e moral das pessoas e situações advindas das ações empresariais. Para isso tem certos princípios: Primazia da ética, responsabilidade social, confiança, integridade, valorização da diversidade e combate à discriminação, diálogo com as partes interessadas, transparência, marketing responsável, interdependência, comunidade de aprendizagem (ETHOS, 2019).

O instituto tem códigos, normas e um extenso questionário e condições para fomentar empresas a uma apropriação da sociedade na qual firma sua economia. Até mesmo para a pandemia que enfrentamos o guia já coloca sua missão no nome: "Enfrentando a Pandemia com Responsabilidade Social", que teve como lançamento um webinar onde a coordenadora Sheila de Carvalho, diz: "é importante observar os impactos da pandemia de forma interseccional (...) há uma perversidade em violações de direitos" (ETHOS, 2019).

Um dos documentos ETHOS criados é o: Indicadores Ethos para Negócios Sustentáveis e Responsáveis, que tem como finalidade oferecer indicadores para maior orientação as empresas de acordo com seus interesses e reflexões sobre o que precisa desenvolver. À medida que são selecionados os indicadores, o Ethos propõe a aplicação nas empresas de um Questionário, de cada dimensão, que aponta as questões que são observadas avaliadas e depois tem um apoio de como 
progredir para estágios até conseguir sair de um estágio de cumprimento até chegar a um estágio de eficiência e protagonismo desta empresa (ETHOS, 2019).

Ainda segundo (Ethos, 2019), a partir do questionário aplicado, se pode avaliar para cada dimensão e tema; os interesses dos shareholder, os aspectos da cultura de responsabilidade social, de comunicação interna e com a comunidade, das organizações.

A dimensão social possui quatro temas que se estende em 16 indicadores que permeiam e levam as corporações a refletir que estágio está conseguindo chegar? Quais são apoiadas com o projeto em propostas de como pode atingir um próximo estágio. O diagnóstico encontrado é indispensável para um comportamento de responsabilidade social, mas mais importante do que o diagnóstico e a consciência responsável da empresa é a decisão e o planejamento que fará a partir destes conhecimentos e indicadores apontados pelo questionário; e para isso a ETHOS também colabora com módulos de planejamento que apoia nesta etapa de Responsabilidade social em que as empresas começam a depositar sua atenção (ETHOS, 2019).

A responsabilidade social citada nos 16 indicadores da dimensão social: Monitoramento De Impactos Do Negócio Nos Direitos Humanos; Combate Ao Trabalho Infantil Na Cadeia De Suprimentos; Trabalho Forçado (ou Análogo ao Escravo; Promoção da Diversidade e Equidade; Relação com Empregados (Efetivos, Terceirizados, Temporários ou Parciais); Relações Com Sindicatos; Remuneração e Benefícios; Compromisso com o Desenvolvimento Profissional; Comportamento Frente a Demissões e Aposentadoria; Saúde e Segurança dos Empregados; Condições de Trabalho, Qualidade de Vida e Jornada de Trabalho; Relacionamento com o Consumidor; Impacto Decorrente do Uso dos Produtos ou Serviços; Estratégia de Comunicação Responsável e Educação para o Consumo Consciente; Estratégia de Comunicação Responsável e Educação para

o Consumo Consciente; Gestão dos Impactos da Empresa na Comunidade; Compromisso com o Desenvolvimento da Comunidade e Gestão das Ações Sociais; Apoio ao Desenvolvimento de Fornecedores (ETHOS, 2019).

O questionário ETHOS permite estabelecer as questões quantitativas e através de pré formatações, e realizam-se as correlações necessárias, que permitem que as corporações vislumbrem e apontem onde transformar e investir com responsabilidade social em um futuro de prosperidade e de mudança na história empresarial do país.

\section{Contexto da Investigação e Alguns Aspectos Sociais da Pandemia}

Discorrer sobre os aspectos sociais da pandemia em meio a ela, não é uma tarefa simples, por estarmos imersos na situação, entretanto, alguns fatos já podemos discutir sobre a dimensão social.

Santos, (2020), chama atenção para o fato de que a questão da pandemia é uma crise imersa em outra crise que assola a humanidade nos últimos 40 anos. A crise que foi imposta pelo modelo neoliberal pressupõe de um pano de fundo para justificar a acumulação por poucos em detrimento ao empobrecimento de muitos. Estamos sempre mergulhados em uma crise, em sua maioria financeira para que se justifique a diminuição de salários, desempregos, precariedade de condições de vida, em oposição a uma acumulação crescente de poucos. Na medida em que o mercado assume a posição de protagonista e o Estado diminui seu espectro de atuação, construído a partir na narrativa de ineficiência, corrupção, burocracia, deixa à margem os cuidados fundamentais da população como a oferta de serviços de saúde, educação, ciência e segurança, que ficam dependentes dos investimentos privados, restringindo dessa forma, o acesso de grande parte da população a tais serviços. Esses reflexos do estado mínimo foram evidenciados durante a pandemia quando assistimos a ausência de infraestrutura mínima de equipamentos e materiais para o enfrentamento adequado às necessidades dos cidadãos.

Por opção ideológica, seguiu-se a demonização dos serviços públicos (o Estado predador, ineficiente ou corrupto); a degradação das políticas sociais ditada pelas políticas de austeridade sob o pretexto da crise financeira do Estado; a privatização dos serviços públicos e o subfinanciamento dos que restaram por não interessarem ao capital. $\mathrm{E}$ 
chegámos aos nossos dias com os Estados sem capacidade efectiva para responderem eficazmente à crise humanitária que se abateu sob os seus cidadãos. A fractura entre a economia da saúde e a saúde pública não podia ser maior. Os governos com menos lealdade ao ideário neoliberal são os que estão a actuar mais eficazmente contra a pandemia, independentemente do regime político. Basta mencionar a Taiwan, Coreia do Sul, Singapura e China (Santos, 2020 p.24).

Corroborando com essa visão, Santos, (2020) e tambem Costa, (2020), atribuem ao sistema capitalista, mais especificamente em sua fase neoliberal a crescente desigualdade social ,que de um lado aumenta as fortunas, e do outro cria o empobrecimento das massas. E quando nos referimos a questão da saúde torna-se evidente a intensificação dessas diferenças que geram oportunidades interessantes de lucro na area da saúde à iniciativa privada. Somos testemunhas que a ausencia do estado na proteção social, apesar do modelo do Sistema Unico de Saúde - SUS, fruto da constituição cidadã de 1988, que universalizalizou o acesso da saúde que foi bastante reconhecido durante essa fase, tambem demonstrou sua incapacidade de respostas efetivas, o que reforça a tese de que é necessario um Estado que garanta o direito a vida. Em paralelo a essa questão também testemunhamos uma crise politica com a tentativa de reducionismo de um Estado a um Governo Federal ausente de articulação com os demais poderes e outros entes Federativos, contrariando dados cientificos em favor da economia, e , negligenciando o dever na defesa a vida.

[...] Nesse momento o Estado deve assumir que seu dever supremo é a defesa da vida, mesmo que o governo federal diga o contrário. O Estado não se reduz ao Presidente da República, é formado pelos poderes Legislativo, Judiciário e Executivo. Ressalte-se que nossa constituição assegura a autonomia dos entes federados. Assim, o governo federal não pode agir de forma a limitar autonomia dos governos estaduais/municipais. A pandemia tem mostrado a importância da autonomia dos entes federados para divergir do governo federal e agir em defesa da vida. O federalismo cooperativo na área social é fundamental para articular as ações dos governos estaduais e municípios, enfrentando a posição do Presidente da República. (Costa, 2020 p. 120)

Mesmo com todos avanços tecnológicos, o Estado foi incapaz de prover o mínimo de estrutura para atender a demanda criada pela pandemia. A ausência de respiradores, água canalizada, saneamento o que tem nos feito testemunha de milhares de mortos. Tudo isso, reflexo de uma opção realizada no final da década de 1970, onde foi dado total priorização ao princípio de mercado com a privatização dos bens sociais coletivos como a saúde, por exemplo, dando protagonismo a mercantilização da vida coletiva. (Córdula, 2020; Santos, 2020 e Mainardi, 2020).

O mundo parou, muitas vidas perdidas pelo colapso causado na saúde, e os países com maior número de mortes foram justamente aqueles que no momento de efetivar a única arma eficaz contra a disseminação incontrolável são aqueles que optaram pelo capital ao invés de vida, que não quiseram parar a produção para frear o causador do Covid-19, países onde tudo é gerador de lucro, inclusive a saúde. Os governantes nunca mostraram tão claramente sua face cruel, mediana ou solidária. Os países, quanto mais adeptos do capitalismo, mas cruéis foram com seus cidadãos com as vítimas, pessoas morreram em casa, sem nenhuma dignidade, outras morreram no hospital, sem o direito primário de dizer adeus aos seus entes queridos (Mainardi, 2020 p.121).

De forma alguma, pretende-se minimizar a importância e gravidade da pandemia, a questão levantada, é que, mesmo diante de um processo que ameaça todo o mundo a prioridade tem como foco principal a manutenção da economia. Em tese a pandemia tem um caráter universal e democrático, entretanto, a realidade nos mostra que ela tem, em função das condições de vida a que estão expostos parte da população ceifada dos direitos fundamentais básicos, sua maior vítima. São grupos que já vivem um estado de vulnerabilidade antes da pandemia. Santos, (2020), elenca alguns grupos que vem sofrendo de forma mais intensa os efeitos da quarentena imposto pela pandemia: a) mulheres; b) os trabalhadores precários, informais, ditos autónomos; c) os trabalhadores de rua; d) os sem abrigo ou população de rua; e) os moradores de periferias pobres das cidades; f) refugiados; g) deficientes e h) idosos. 
Santos, (2020) destaca que a quarentena revelou que as mulheres que assumem o papel social de cuidadoras, são majoritariamente aquelas que exercem a função de cuidados dentro e fora de seu espaço familiar. Ademais são elas que estão em maior número entre as profissões que estão na linha de frente de combate a Covid-19, seja como enfermeiras os assistentes sociais, cujas funções não permitem a utilização do "novo normal" através do home office. Além disso as tarefas em seu lar devem ser redobradas em função de maior número de pessoas em assa, e que devido a um processo histórico de machismo, ainda atribui a ela as obrigações com os cuidados domésticos. Esse ambiente gera um processo de stress que tem se configurado em dados como o aumento do número de divórcio na China e o aumento da violência doméstica em $36 \%$ em Paris, conforme o jornal le Fígaro, em março 2020 (Le Figaro, 2020).

Devido a desregulamentação dos direitos trabalhistas, Santos, (2020), evidencia o surgimento de uma nova legião de "autônomos, informais", que não possuem nenhum direito trabalhista fruto das medidas de modernização das relações de trabalho. Estima-se que cerca de 50\% dos empregos na américa latina são informais e na índia esse número equivale a 300 milhões de trabalhadores, que dependem de um salário diário e dentro da atual realidade vive o conflito entre a proteção e a sobrevivência sua e de sua família. Os trabalhadores da rua que também expõe a perversa precariedade do trabalho, dependem as ruas para garantir seu sustento. Com as medidas de isolamento tanto a ausência de clientes quanto o risco a contaminação deixam esse grupo também em um estado de alta vulnerabilidade.

Já os moradores de rua, adverte Santos, (2020), cuja condição preexiste a pandemia, estão na contramão das orientações cientificas de combate a pandemia. Sem acesso as condições mínimas de higiene, estão expostos ao vírus, dormindo em calçadas, viadutos dos grandes centros urbanos. Em situação similar vivem os moradores das periferias dos grandes centros, que apesar de possuírem um espaço vivem sem acesso as infraestruturas mínimas necessárias as condições de quarentena, como isolamento social, acesso a água e saneamento, e muitas vezes são trabalhadores informais ou trabalhadores de rua.

Os refugiados, também pelas condições em que estão inseridos em campos para refugiados em todo mundo, também configuram um grupo vulnerável, além dos deficientes e idosos, cujas políticas públicas os mantem fora do contexto, visto que não se enquadram no padrão de produção, e também porque os mesmos necessitam de cuidados de outras pessoas, ou do Estado em alguns casos. Portanto o endereço das possíveis vítimas da pandemia assim está traçado Santos, (2020 p.15-21).

Por um lado, ao contrário do que é veiculado pelos media e pelas organizações internacionais, a quarentena não só torna mais visíveis, como reforça a injustiça, a discriminação, a exclusão social e o sofrimento imerecido que elas provocam. Acontece que tais assimetrias se tornam mais invisíveis em face do pânico que se apodera dos que não estão habituados a ele (Santos, 2020 p.21).

Silva e Dal Bosco, (2020), ao referirem a questão da segurança alimentar nas comunidades periféricas traça um interessante paralelo sobre asas condições em que ocorreram nas pandemias da gripe espanhola e a Covid-19. Nas pesquisas realizadas as autoras identificaram que nos dois casos houve por conta das autoridades brasileiras um descaso quanto a dimensão da doença, minimizando sua gravidade. Da mesma forma as estruturas de saúde existentes não estavam devidamente preparadas para enfrentar uma situação de tal magnitude. Também o número de óbitos em números expressivos que nos dois casos acarretaram no enterro dos corpos em valas comuns em muitos casos. Da mesma forma a precariedade das relações de trabalhos tanto durante a gripe espanhola em que empregados eram obrigados a trabalhar e ao contrair a doença eram demitidos, quanto na Covid-19 onde houve medidas de flexibilização sob o pretexto da manutenção do emprego, mas o que acarretou em diminuição de renda ou mesmo suspensão completa durante toda a pandemia. Além disso as populações das periferias, assim como na gripe espanhola, ainda se encontram nas mesmas condições sanitárias, sem acesso a água e outras 
medidas profiláticas básicas para proteção desses grupos. São cem anos o intervalo entre as duas pandemias, entretanto o cenário em que ocorreram, salvo os avanços tecnológicos, permanecem semelhantes.

Portanto é neste quadro complexo em que surgiu a pandemia da Covid-19, que as empresas com suas ações de responsabilidade social e com o investimento social privado surge na tentativa de apoiar sob diversas perspectivas o enfrentamento a pandemia, cujas motivações merece uma investigação mais detalhada. De qualquer forma, o setor empresarial vem gradativamente assumindo pautas como os direitos humanos, igualdade, qualidade de vida, educação e agora a de socorro a população durante a pandemia.

\section{Resultados}

Os questionários após serem previamente definidos em questões objetivas e semiestruturadas, foram aplicados nas empresas, sempre com um gestor que tivesse pleno conhecimento de todas as ações referentes a Covid-19 na empresa. O Modelo de questionário e sua aplicação seguiram rigorosamente todas as etapas metodológicas anteriormente descritas, inclusive com a classificação temática proposta pelo Instituto Ethos. O Quadro 1 a seguir contém todas as perguntas que forma aplicada nas três empresas pesquisadas e suas respectivas classificações temáticas.

Quadro 1 - Perguntas do Questionário aplicado e as classificações temáticas.

\begin{tabular}{|c|c|}
\hline Perguntas & Temas \\
\hline $\begin{array}{l}\text { A empresa formou um comitê multidisciplinar para gestão do } \\
\text { enfrentamento a Covid? }\end{array}$ & Gestão e Planejamento \\
\hline $\begin{array}{l}\text { Quais foram as diretrizes estratégicas definidas pela empresa com } \\
\text { relação ao enfrentamento? }\end{array}$ & Gestão e Planejamento \\
\hline $\begin{array}{l}\text { Quais ações foram planejadas e executadas com relação a empregados, } \\
\text { cliente e fornecedores? }\end{array}$ & $\begin{array}{l}\text { Saúde e Segurança no Trabalho e } \\
\text { Qualidade de Vida }\end{array}$ \\
\hline $\begin{array}{l}\text { Houve casos de empregados contaminados? Que ações foram } \\
\text { tomadas? }\end{array}$ & $\begin{array}{l}\text { Saúde e Segurança no Trabalho e } \\
\text { Qualidade de Vida }\end{array}$ \\
\hline Houve ações destinadas aos familiares dos empregados? & $\begin{array}{l}\text { Saúde e Segurança no Trabalho e } \\
\text { Qualidade de Vida }\end{array}$ \\
\hline Qual \% funcionários passou trabalhar com Home Office? & $\begin{array}{l}\text { Saúde e Segurança no Trabalho e } \\
\text { Qualidade de Vida }\end{array}$ \\
\hline Empresa ofereceu suporte para trabalho com Home office? & Gestão e planejamento \\
\hline Houve redução de jornada trabalho? Se sim houve redução de salário? & Relações de Trabalho \\
\hline $\begin{array}{l}\text { Houve adesão dos funcionários nas medidas preventivas adotadas pela } \\
\text { empresa? }\end{array}$ & $\begin{array}{l}\text { Saúde e Segurança no Trabalho e } \\
\text { Qualidade de Vida }\end{array}$ \\
\hline A empresa realizou alguma ação junto à comunidade? Quais? & $\begin{array}{l}\text { Gestão de Impactos na Comunidade e } \\
\text { Desenvolvimento }\end{array}$ \\
\hline $\begin{array}{l}\text { Se a empresa realizou ações com a comunidade, esta participou da fase } \\
\text { de planejamento? }\end{array}$ & $\begin{array}{l}\text { Gestão de Impactos na Comunidade e } \\
\text { Desenvolvimento }\end{array}$ \\
\hline $\begin{array}{l}\text { A empresa destinou algum apoio a esfera pública? - Hospitais, sec. De } \\
\text { saúde? CRAS? }\end{array}$ & Envolvimento Político Responsável \\
\hline $\begin{array}{l}\text { Houve interlocução constante com o poder público nas decisões das } \\
\text { ações? }\end{array}$ & Envolvimento Político Responsável \\
\hline $\begin{array}{l}\text { Houve alguma interrupção das atividades ou parte dela em função da } \\
\text { pandemia? }\end{array}$ & Gestão e planejamento \\
\hline $\begin{array}{l}\text { Qual o valor de investimentos realizados em função da pandemia na } \\
\text { área social }\end{array}$ & $\begin{array}{l}\text { Gestão de Impactos na Comunidade e } \\
\text { Desenvolvimento }\end{array}$ \\
\hline $\begin{array}{l}\text { Qual a perspectiva da empresa junto a seus empregados fornecedores e } \\
\text { clientes com relação ao novo normal } i\end{array}$ & $\begin{array}{l}\text { Gestão de Impactos na Comunidade e } \\
\text { Desenvolvimento }\end{array}$ \\
\hline
\end{tabular}

Fonte: Autores. 
As respostas ao questionário, que foram realizadas de forma presencial, por um dos pesquisadores em contato direto com o gestor da empresa, são apresentados a seguir, sendo no Quadro 2 se apresentam as respostas da Cooperativa de Credito.

Quadro 2 - Respostas ao Questionário da Cooperativa de Credito.

\begin{tabular}{|c|c|}
\hline PERGUNTAS: COOPERATIVA DE CREDITO & TEMAS \\
\hline $\begin{array}{l}\text { A empresa formou um comitê multidisciplinar para gestão do } \\
\text { enfrentamento a Covid? Sim a cooperativa instalou um comitê } \\
\text { interdisciplinar de monitoramento, centralização e coordenação das ações }\end{array}$ & Gestão e Planejamento \\
\hline $\begin{array}{l}\text { Quais foram às diretrizes estratégicas definidas pela empresa com relação } \\
\text { ao enfrentamento? Diversas medidas foram implementadas: home office } \\
\text { para os funcionários que pudessem redução de horário atendimento nas } \\
\text { agências, redução salarial de } 30 \% \text { para todos os funcionários, diretores e } \\
\text { conselheiros, utilização de mascaras, álcool gel e distanciamento social } \\
\text { nos atendimentos. Ainda que a empresa não realizou demissões. }\end{array}$ & Gestão e Planejamento \\
\hline $\begin{array}{l}\text { Quais ações foram planejadas e executadas com relação a empregados, } \\
\text { cliente e fornecedores? Distanciamento social nos atendimentos, uso de } \\
\text { mascaras, instalação álcool gel, reuniões por vídeo conferencia para } \\
\text { todos os funcionários, diretores e conselheiros }\end{array}$ & $\begin{array}{l}\text { Saúde e Segurança no Trabalho e } \\
\text { Qualidade de Vida }\end{array}$ \\
\hline $\begin{array}{l}\text { Houve casos de empregados contaminados? Que ações foram tomadas? } \\
\text { Sim foram sete contaminados e nenhum óbito, a Cooperativa realizou a } \\
\text { contratação de } 1 \text { médico do trabalho, que com sinais de sintomas iniciais } \\
\text { fazia tele consulta passando as orientações e, se necessário, e fazendo o } \\
\text { afastamento preventivo, inclusive orientando os familiares dos } \\
\text { contaminados. }\end{array}$ & $\begin{array}{l}\text { Saúde e Segurança no Trabalho e } \\
\text { Qualidade de Vida }\end{array}$ \\
\hline $\begin{array}{l}\text { Houve ações destinadas aos familiares dos empregados? Não } \\
\text { diretamente, mas quando tinha um parente com sintomas ou já afastado o } \\
\text { nosso médico fazia as orientações aos nossos empregados. }\end{array}$ & $\begin{array}{l}\text { Saúde e Segurança no Trabalho e } \\
\text { Qualidade de Vida }\end{array}$ \\
\hline $\begin{array}{l}\text { Qual \% funcionários passou trabalhar com Home Office? Os } 66 \\
\text { funcionários da sede administrativa, passaram a trabalhar em home } \\
\text { office, os demais } 123 \text { funcionários das agências não tinham como fazer o } \\
\text { tele trabalho e trabalharam normalmente com jornada reduzida, e } \\
\text { atendendo os cooperados. }\end{array}$ & $\begin{array}{l}\text { Saúde e Segurança no Trabalho e } \\
\text { Qualidade de Vida }\end{array}$ \\
\hline $\begin{array}{l}\text { Empresa ofereceu suporte para trabalho com Home office? Sim a } \\
\text { empresa permitiu uso de laptops da empresa nas residências }\end{array}$ & Gestão e planejamento \\
\hline $\begin{array}{l}\text { Houve redução de jornada trabalho? Se sim houve redução de salário? } \\
\text { Sim houve redução de salário de } 30 \% \text { para todos, conforme previsão } \\
\text { legal, e não houve redução de jornada de trabalho. }\end{array}$ & Relações de Trabalho \\
\hline $\begin{array}{l}\text { Houve adesão dos funcionários nas medidas preventivas adotadas pela } \\
\text { empresa? Sim os funcionários aderiram a todas as medidas, inclusive } \\
\text { com a redução salarial. }\end{array}$ & $\begin{array}{l}\text { Saúde e Segurança no Trabalho e } \\
\text { Qualidade de Vida }\end{array}$ \\
\hline $\begin{array}{l}\text { A empresa realizou alguma ação junto à comunidade? Quais? Nenhuma } \\
\text { ação especifica na comunidade, mas adotaram-se ações junto aos seus } \\
17.000 \text { cooperados, divulgando vídeos institucionais das medidas } \\
\text { preventivas contra pandemia e as ações tomadas com relação ao } \\
\text { atendimento nas agências. }\end{array}$ & $\begin{array}{l}\text { Gestão de Impactos na Comunidade e } \\
\text { Desenvolvimento }\end{array}$ \\
\hline $\begin{array}{l}\text { Se a empresa realizou ações com a comunidade, esta participou da fase } \\
\text { de planejamento? Não existiram ações coordenadas com a comunidade. }\end{array}$ & $\begin{array}{l}\text { Gestão de Impactos na Comunidade e } \\
\text { Desenvolvimento }\end{array}$ \\
\hline $\begin{array}{l}\text { A empresa destinou algum apoio a esfera pública? - Hospitais, sec. De } \\
\text { saúde? CRAS? Nenhum apoio para a esfera pública, entretanto foram } \\
\text { feitas ações de arrecadação para entidades assistenciais somente na sede, } \\
\text { na cidade de Presidente Prudente. }\end{array}$ & Envolvimento Político Responsável \\
\hline $\begin{array}{l}\text { Houve interlocução constante com o poder público nas decisões das } \\
\text { ações? Nenhum tipo de interlocução especifica }\end{array}$ & Envolvimento Político Responsável \\
\hline $\begin{array}{l}\text { Houve alguma interrupção das atividades ou parte dela em função da } \\
\text { pandemia? Nenhuma interrupção das atividades, somente adoção horário } \\
\text { reduzido de atendimento aos cooperados. }\end{array}$ & Gestão e planejamento \\
\hline Qual o valor de investimentos realizados em função da pandemia na área & Gestão de Impactos na Comunidade e \\
\hline
\end{tabular}




\begin{tabular}{|l|l|}
\hline social? Não houveram investimentos específicos. & Desenvolvimento \\
\hline Qual a perspectiva da empresa junto a seus empregados fornecedores e & Gestão de Impactos na Comunidade e \\
clientes com relação ao novo normal. A cooperativa tem seu foco atuação & Desenvolvimento \\
em pequenas e medias empresas em 17 cidades do estado de São Paulo, & \\
sendo este segmento um dos mais afetados pela pandemia. As & \\
perspectivas são de promover renegociação de dívidas neste segmento, & \\
realizar provisões financeiras para prevenir inadimplência. Com relação & \\
aos funcionários, a expectativa e' recompor os salários reduzidos até o \\
final de 2020, e para o atendimento nas agências, retomar o atendimento \\
normal em conformidade com o Plano São Paulo, definido pelo governo \\
estadual, uma vez que a base de todas agencias é no estado.
\end{tabular}

Fonte: Autores.

Os resultados obtidos com o questionário mostram uma preocupação da empresa no enfrentamento da pandemia, com a criação de um comitê gestor para o monitoramento das ações. Este comitê interdisciplinar tem importância na coordenação, centralização e monitoramento de todas as ações emergenciais que a empresa vem tomando no enfrentamento desta nova realidade.

A própria inexistência de protocolos e procedimentos pré-estabelecidos, fez a empresa criar seus próprios protocolos, à medida que a pandemia avançava, seguindo as ações básicas tais como: desmobilização álcool gel, distanciamento entre os funcionários e clientes, trabalho remoto para todos os funcionários que tinham condições de fazê-lo e uso de mascaras. Houve uma inovação no sentido da contratação de um médico do trabalho, para orientar os funcionários e seus familiares com sintomas da Covid-19, acompanhar aqueles que efetivamente foram contaminados; ainda que esta ação importante não foi estendida para os clientes da empresa.

Denota-se pouca coordenação e cooperação da empresa com os órgãos públicos de saúde, quer sejam municipais, estaduais e federais; não cabe neste momento buscar culpados, se faltou pró-atividade destes órgãos públicos, ou até mesmo a empresa procura-los, no sentido de potencializar ações, que pudessem ser mais efetivas em toda comunidade; entretanto a empresa realizou ações coordenadas com entidades não governamentais para arrecadação de fundos monetários, e uma comunicação por meio de vídeos, que de algum modo contribuíram na divulgação e conscientização da comunidade e arrecadação recursos financeiros.

Medidas emergências importantes e impactantes nas relações de trabalho da empresa com seus colaboradores foram tomadas, com a redução de $30 \%$ dos salários e não foram realizadas demissões; o processo de comunicação destas medidas foi importante para não se criar atritos e gerar comprometimento, nestas relações.

O relacionamento da empresa tanto a montante, e principalmente a jusante com seus clientes, foi totalmente modificado em diversos aspectos: horário de atendimento, novos canais de comunicação não presenciais; entretanto a empresa não cessou atendimento nas linhas de credito para seus cooperados, e teve uma postura proativa de realizar renegociações de dívidas que estavam vencendo, ainda disponibilizando novas linhas de créditos para as empresas cooperadas que tivessem sido mais impactadas pela crise.

No Quadro 3 a seguir tem-se as respostas ao Questionário da empresa de Tratamento de Madeira localizada no estado do Mato Grosso do Sul. 
Quadro 3 - Respostas ao Questionário da Empresa de Tratamento de Madeira.

\begin{tabular}{|c|c|}
\hline PERGUNTAS: TRATAMENTO DE MADEIRA & TEMAS \\
\hline $\begin{array}{l}\text { A empresa formou um comitê multidisciplinar para gestão do } \\
\text { enfrentamento a Covid? Não formou, pois não achou necessário pela } \\
\text { unidade de produção estar localizada em uma Propriedade Rural distante } \\
\text { de } 65 \mathrm{~km} \text { da cidade. }\end{array}$ & Gestão e Planejamento \\
\hline $\begin{array}{l}\text { Quais foram às diretrizes estratégicas definidas pela empresa com relação } \\
\text { ao enfrentamento? Manteve o mesmo ritmo de trabalho, somente com a } \\
\text { recomendação do uso de máscaras e álcool gel. }\end{array}$ & Gestão e Planejamento \\
\hline $\begin{array}{l}\text { Quais ações foram planejadas e executadas com relação a empregados, } \\
\text { cliente e fornecedores? Não foram adotadas medidas mais efetivas, além } \\
\text { do uso máscara e álcool gel. }\end{array}$ & $\begin{array}{l}\text { Saúde e Segurança no Trabalho e } \\
\text { Qualidade de Vida }\end{array}$ \\
\hline $\begin{array}{l}\text { Houve casos de empregados contaminados? Que ações foram tomadas? } \\
\text { Sim um funcionário foi infectado e ficou } 12 \text { dias internado na cidade } \\
\text { Cassilândia MS, houve monitoramento diário da empresa sobre estado } \\
\text { saúde do funcionário, que já retornou ao trabalho. Todos demais } \\
\text { funcionários realizaram o teste para Covid e nenhum outro esteve } \\
\text { contaminando. }\end{array}$ & $\begin{array}{l}\text { Saúde e Segurança no Trabalho e } \\
\text { Qualidade de Vida }\end{array}$ \\
\hline $\begin{array}{l}\text { Houve ações destinadas aos familiares dos empregados? Nenhuma ação } \\
\text { foi tomada com relação aos parentes de funcionários. }\end{array}$ & $\begin{array}{l}\text { Saúde e Segurança no Trabalho e } \\
\text { Qualidade de Vida }\end{array}$ \\
\hline $\begin{array}{l}\text { Qual \% funcionários passou trabalhar com Home Office? Zero, pelo tipo } \\
\text { de atividade desenvolvida pela empresa, somente uma funcionaria } \\
\text { administrativa, manteve sua atividade, pois já trabalha isolada em uma } \\
\text { sala. }\end{array}$ & $\begin{array}{l}\text { Saúde e Segurança no Trabalho e } \\
\text { Qualidade de Vida }\end{array}$ \\
\hline $\begin{array}{l}\text { Empresa ofereceu suporte para trabalho com Home office? Não houve } \\
\text { necessidade }\end{array}$ & Gestão e planejamento \\
\hline $\begin{array}{l}\text { Houve redução de jornada trabalho? Se sim houve redução de salário? Não } \\
\text { houve redução de jornada, nem redução salarial. }\end{array}$ & Relações de Trabalho \\
\hline $\begin{array}{l}\text { Houve adesão dos funcionários nas medidas preventivas adotadas pela } \\
\text { empresa? Sim os funcionários aderiram às medidas preventivas }\end{array}$ & $\begin{array}{l}\text { Saúde e Segurança no Trabalho e } \\
\text { Qualidade de Vida }\end{array}$ \\
\hline $\begin{array}{l}\text { A empresa realizou alguma ação junto à comunidade? Quais? Não houve } \\
\text { qualquer tipo de ação da empresa junto à comunidade }\end{array}$ & $\begin{array}{l}\text { Gestão de Impactos na Comunidade e } \\
\text { Desenvolvimento }\end{array}$ \\
\hline $\begin{array}{l}\text { Se a empresa realizou ações com a comunidade, esta participou da fase de } \\
\text { planejamento? Prejudicada }\end{array}$ & $\begin{array}{l}\text { Gestão de Impactos na Comunidade e } \\
\text { Desenvolvimento }\end{array}$ \\
\hline $\begin{array}{l}\text { A empresa destinou algum apoio a esfera pública? - Hospitais, sec. De } \\
\text { saúde? CRAS? Não realizou nenhum apoio }\end{array}$ & Envolvimento Político Responsável \\
\hline $\begin{array}{l}\text { Houve interlocução constante com o poder público nas decisões das ações? } \\
\text { Não }\end{array}$ & Envolvimento Político Responsável \\
\hline $\begin{array}{l}\text { Houve alguma interrupção das atividades ou parte dela em função da } \\
\text { pandemia? Nenhuma Interrupção }\end{array}$ & Gestão e planejamento \\
\hline $\begin{array}{l}\text { Qual o valor de investimentos realizados em função da pandemia na área } \\
\text { social. Nenhum investimento significativo }\end{array}$ & $\begin{array}{l}\text { Gestão de Impactos na Comunidade e } \\
\text { Desenvolvimento }\end{array}$ \\
\hline $\begin{array}{l}\text { Qual a perspectiva da empresa junto a seus empregados fornecedores e } \\
\text { clientes com relação ao novo normal. A empresa como manteve suas } \\
\text { atividades normalmente, a expectativa e "que as atividades continuem } \\
\text { normalmente. }\end{array}$ & $\begin{array}{l}\text { Gestão de Impactos na Comunidade e } \\
\text { Desenvolvimento }\end{array}$ \\
\hline
\end{tabular}

Fonte: Autores.

A empresa de tratamento de madeira adotou poucas medidas preventivas no combate a Covid-19, apenas disponibilização de álcool gel e uso de mascaras, os trabalhos da empresa seguiram normalmente sem que houvesse qualquer tipo de interrupção ou modificação nas relações de trabalho com os funcionários; bem como nas tratativas com os clientes e fornecedores.

O fato de um dos funcionários, inclusive em cargo gerencial, ter sido infectado e ter ficado hospitalizado por período de aproximadamente 10 dias, não modificou as ações da empresa nas ações preventivas e de gerenciamento. Ainda que pelo próprio distanciamento da unidade de produção localizada em uma fazenda distante $70 \mathrm{~km}$ da cidade, houve uma percepção equivocada por parte dos proprietários da empresa, gestores e os próprios funcionários; de que a Covid-19 nunca chegaria por lá, o que se mostrou um equívoco. 
Finalmente que a empresa e seus gestores, não realizaram nenhuma ação de comunicação para com seus funcionários, clientes e fornecedores; no sentido de mitigar os riscos da Covid-19, nem mesmo após a contaminação efetivada em um dos funcionários da empresa.

No Quadro 4 a seguir têm-se as respostas ao Questionário do Curtume de couros localizado na cidade de Araçatuba-

SP.

Quadro 4 - Respostas ao Questionário do Curtume.

\begin{tabular}{|c|c|}
\hline PERGUNTAS: CURTUME & TEMAS \\
\hline $\begin{array}{l}\text { A empresa formou um comitê multidisciplinar para gestão do } \\
\text { enfrentamento a Covid? Não constituiu nenhum comitê }\end{array}$ & Gestão e Planejamento \\
\hline $\begin{array}{l}\text { Quais foram às diretrizes estratégicas definidas pela empresa com relação } \\
\text { ao enfrentamento? Medidas preventivas de uso obrigatório de mascaras, } \\
\text { uso álcool gel, lavar as mãos pelo menos três vezes ao dia. }\end{array}$ & Gestão e Planejamento \\
\hline $\begin{array}{l}\text { Quais ações foram planejadas e executadas com relação a empregados, } \\
\text { cliente e fornecedores? Uso de máscara, de álcool gel, e para evitar } \\
\text { aglomerações à empresa acabou com sua sala de espera para clientes e } \\
\text { fornecedores. }\end{array}$ & $\begin{array}{l}\text { Saúde e Segurança no Trabalho e } \\
\text { Qualidade de Vida }\end{array}$ \\
\hline $\begin{array}{l}\text { Houve casos de empregados contaminados? Que ações foram tomadas? } \\
\text { Ninguém foi contaminado }\end{array}$ & $\begin{array}{l}\text { Saúde e Segurança no Trabalho e } \\
\text { Qualidade de Vida }\end{array}$ \\
\hline $\begin{array}{l}\text { Houve ações destinadas aos familiares dos empregados? Nenhum tipo de } \\
\text { ação neste sentido }\end{array}$ & $\begin{array}{l}\text { Saúde e Segurança no Trabalho e } \\
\text { Qualidade de Vida }\end{array}$ \\
\hline $\begin{array}{l}\text { Qual \% funcionários passou trabalhar com Home Office? Nenhum } \\
\text { funcionário passou a trabalhar em Home Office, todos compareceram } \\
\text { normalmente na empresa. }\end{array}$ & $\begin{array}{l}\text { Saúde e Segurança no Trabalho e } \\
\text { Qualidade de Vida }\end{array}$ \\
\hline $\begin{array}{l}\text { Empresa ofereceu suporte para trabalho com Home office? Não houve } \\
\text { necessidade, são poucos funcionários administrativos, e maior parte } \\
\text { funcionários trabalham na fabrica }\end{array}$ & Gestão e planejamento \\
\hline $\begin{array}{l}\text { Houve redução de jornada trabalho? Se sim houve redução de salário? } \\
\text { Manteve-se a jornada de trabalho e não houve nenhuma redução salarial }\end{array}$ & Relações de Trabalho \\
\hline $\begin{array}{l}\text { Houve adesão dos funcionários nas medidas preventivas adotadas pela } \\
\text { empresa? Sim houve adesão total dos funcionários nas medidas adotadas } \\
\text { na empresa }\end{array}$ & $\begin{array}{l}\text { Saúde e Segurança no Trabalho e } \\
\text { Qualidade de Vida }\end{array}$ \\
\hline $\begin{array}{l}\text { A empresa realizou alguma ação junto à comunidade? Quais? Nenhuma } \\
\text { ação junto à comunidade foi realizada }\end{array}$ & $\begin{array}{l}\text { Gestão de Impactos na Comunidade e } \\
\text { Desenvolvimento }\end{array}$ \\
\hline $\begin{array}{l}\text { Se a empresa realizou ações com a comunidade, esta participou da fase de } \\
\text { planejamento? Prejudicada }\end{array}$ & $\begin{array}{l}\text { Gestão de Impactos na Comunidade e } \\
\text { Desenvolvimento }\end{array}$ \\
\hline $\begin{array}{l}\text { A empresa destinou algum apoio a esfera pública? - Hospitais, sec. De } \\
\text { saúde? CRAS? Não destinou nenhum apoio }\end{array}$ & Envolvimento Político Responsável \\
\hline $\begin{array}{l}\text { Houve interlocução constante com o poder público nas decisões das ações? } \\
\text { Somente a Vigilância Sanitária Municipal realizou duas visitas de } \\
\text { fiscalização das medidas preventivas na empresa. }\end{array}$ & Envolvimento Político Responsável \\
\hline $\begin{array}{l}\text { Houve alguma interrupção das atividades ou parte dela em função da } \\
\text { pandemia? Nenhuma interrupção das atividades da empresa, pois o couro } \\
\mathrm{e}^{\prime} \text { um produto perecível }\end{array}$ & Gestão e planejamento \\
\hline $\begin{array}{l}\text { Qual o valor de investimentos realizados em função da pandemia na área } \\
\text { social. Valores insignificantes, com compra de mascaras, álcool gel e } \\
\text { desinfetante. }\end{array}$ & $\begin{array}{l}\text { Gestão de Impactos na Comunidade e } \\
\text { Desenvolvimento }\end{array}$ \\
\hline $\begin{array}{l}\text { Qual a perspectiva da empresa junto a seus empregados fornecedores e } \\
\text { clientes com relação ao novo normal. A pandemia não afetou as atividades } \\
\text { da empresa e nem sua cadeia produtiva, e a perspectiva as atividades } \\
\text { continuem normais. }\end{array}$ & $\begin{array}{l}\text { Gestão de Impactos na Comunidade e } \\
\text { Desenvolvimento }\end{array}$ \\
\hline
\end{tabular}

Fonte: Autores.

Os dados coletados com o questionário no curtume demonstram que a empresa somente adotou as medidas básicas de prevenção, como: obrigatoriedade no uso de máscara para todos os funcionários, disponibilização de álcool gel, exigir lavagem das mãos antes e na saída dos funcionários. Nenhuma medida de distanciamento social foi efetivada, pelas características operacionais da empresa, e que a empresa não interrompeu suas atividades, e manteve o mesmo relacionamento com clientes e fornecedores. 
A maior parte dos funcionários trabalha, no processamento operacional do couro, e com poucos funcionários administrativos; neste diapasão a empresa manteve todos seus funcionários trabalhando normalmente, sem qualquer tipo de afastamento, não realizou redução salarial prevista em lei, e também não efetuou nenhuma demissão, com a manutenção normal da produção.

Mesmo com a fiscalização realizada pela vigilância sanitária municipal, a empresa não fez qualquer tipo de ação integrada com os órgãos públicos. A comunicação da empresa para com seus funcionários foi impositiva e restrita a obrigatoriedade das ações profiláticas anteriormente descritas, não efetivando qualquer tipo comunicação em consonância com os preceitos teóricos descritos neste artigo.

Houve somente a preocupação por parte dos gestores e proprietários da empresa, em garantir o funcionamento do negócio, e exigir medidas básicas de prevenção, para que nenhum dos funcionários fosse contaminado; mas efetivamente não realizou uma comunicação adequada dos riscos e problemas que uma eventual contaminação de funcionários pudesse gerar a paralisação da empresa.

Percebe-se que os órgãos públicos, em especial a vigilância sanitária, mesmo realizando fiscalização na empresa, não foi proativa para recomendar medidas de comunicação adequadas no enfrentamento da Covid-19; restringindo-se aos seus protocolos básicos de fiscalização e verificando, se as ações básicas estavam sendo cumpridas.

\section{Discussão dos Resultados}

Os resultados obtidos em três empresas de diferentes segmentos empresariais, localização geográfica totalmente distinta, trazem um importante recorte das diferentes formas como as empresas investigadas fizeram frente à pandemia na comunicação e enfrentamento ao Covid-19; cabe ressaltar que os diferentes níveis governamentais não estabeleceram protocolos mínimos de ação e atuação, deixando cada uma das empresas adotarem as medidas que julgavam mais convenientes para sua situação momentânea.

Neste sentido a cooperativa de credito, parece que adotou medidas mais estratégicas de atuação, com ações mais coordenadas e proativas; sendo que o comitê gestor da crise criado, trouxe maior agilidade nas decisões e suas implementações, e mesmo assim a comunicação das ações teve maior ênfase nas relações de trabalho com seus funcionários, e algumas ações com seus clientes.

A comunicação, entretanto, não seguiu qualquer padrão do referencial teórico discutido neste texto, e observam-se ações e comportamentos voluntariosos, com intuito do enfrentamento da nova situação pandêmica instalada.

As duas outras empresas pesquisadas, o curtume e a empresa de tratamento de madeira, não realizaram ações de comunicação interna ou externa; atendo-se a seguir os protocolos mínimos, que foram amplamente divulgados pela mídia: disponibilização álcool gel, uso de máscara, lavar as mãos com maior frequência. Não existiram ações efetivas de comunicação com os funcionários, clientes ou fornecedores; no sentido de conscientização, monitoramento e integração de ações com órgãos públicos.

Nesta pesquisa não se busca estabelecer, se os procedimentos foram corretos ou erráticos; somente uma coleta das informações das medidas que foram tomadas pela empresa, e estabelecer os eventuais condutos com a teoria de comunicação; e neste sentido as três empresas pesquisadas, não procuraram profissionais que pudessem orientar e coordenar as importantes ações de comunicação empresarial para fazer frente a esta significativa mudança no ambiente empresarial, pelo Covid-19.

As empresas foram mais ou menos proativas, adotando sempre uma postura tímida de suas ações internas e no seu entorno de relacionamentos empresariais; não utilizando de ferramentas e conceitos já consolidados de comunicação e RSE para coordenar suas ações a nível empresarial, e principalmente com órgãos governamentais. 


\section{Conclusão}

A investigação conduzida, mesmo sendo exploratória, busca melhor compreender os impactos sofridos pelas empresas pesquisadas, no Covid-19; sendo realizada ainda durante os efeitos sofridos pela doença. O objetivo principal de compreender como as empresas se mobilizaram diante de um cenário tão adverso de crise, e ainda analisar as ações e medidas adotadas no enfrentamento, frente às orientações da OMS e os guias de orientação de responsabilidade social empresarial.

Metodologicamente trata-se de uma pesquisa qualitativa, que seguiu todos os protocolos recomendados para este tipo de pesquisa, com a elaboração e aplicação de questionários semiestruturados, e uma análise de conteúdo. Ainda que se optou por disponibilizar os questionários respondidos no próprio texto, para dar uma real dimensão dos dados que foram coletados. A amostra das empresas ficou restrita a três empresas, de diferentes segmentos empresariais, em atividades muito distintas (cooperativa de credito, curtume e unidade tratamento de madeira), com escolha por conveniência, pela facilidade de coleta de dados, e que também traz um recorde geográfico e da diversidade das empresas.

Os resultados se apresentam basicamente na confirmação de que as empresas pesquisadas, somente adotaram as medidas básicas das recomendações da OMS: uso obrigatório de mascaras, distanciamento social quando possível e disponibilização de álcool gel. Não se identifica ações efetivas de comunicação por parte das empresas, buscando mitigar os riscos da Covid-19, junto a seus funcionários, clientes e fornecedores; no caso especifico da cooperativa de credito percebe-se algum avanço, principalmente com a criação de comitê interdisciplinar para coordenar e avaliar as ações tomadas, contratação de um médico para realizar orientações e acompanhamento de casos confirmados e suspeitos.

Ainda se consta uma total falta de comunicação e principalmente de coordenação dos órgãos públicos (federal, estadual e municipal) com as empresas no sentido de realizar uma comunicação adequada para o enfrentamento da pandemia instalada; e nenhum tipo de ação integrada foi minimamente identificado.

As empresas procuram implantar os protocolos mínimos profiláticos, e seguir com suas atividades empresariais, pontualmente realizando algum tipo de ação corretiva, mas sem qualquer comunicação em consonância com a teoria descrita no presente artigo.

Este artigo por ter sido conduzido ao longo da pandemia, traz apenas um recorde do momento em que estamos vivenciando, e deste modo se apresenta com restrições importantes, que passam pela amostra ser muito pequena, e mesmo com empresas de diferentes segmentos, não compõem uma boa representatividade dos diversos ambientes e setores empresariais.

Ainda como restrição importante, a coleta de dados ter sido realizada somente com os gestores das empresas, sem ouvir os funcionários, clientes e fornecedores; os traz um viés que pode ter distorção da percepção destes agentes entrevistados.

Novas e importantes linhas de pesquisa para trabalhos futuros, emergem desta pesquisa, em especial na identificação de como melhor compreender os mecanismos de comunicação que foram adotados pelas empresas; e de que maneira as falhas de comunicação encontradas podem ser aperfeiçoadas. Ainda como outra linha importante para pesquisas futuras, de como conectar de maneira efetiva a responsabilidade social com os conceitos de comunicação empresarial em crises enfrentadas pelas empresas.

Finalmente, entende-se que o objetivo principal desta investigação foi plenamente atingido, para identificar as diferentes abordagens utilizadas pelas empresas pesquisadas, na sua comunicação empresarial, sob ótica da responsabilidade social; notadamente constatando-se um processo totalmente falho, sem coordenação interna e externa com órgãos públicos. 


\section{Referências}

ABCR. (2021). Associação Brasileira de Captadores de Recursos. https://www.monitordasdoacoes.org.br/pt.

Bardin, L. (2011). Análise de Conteúdo. Educações.

Borger, F. G. (2013). Responsabilidade social empresarial e sustentabilidade para a gestão empresarial. https://www.ethos.org.br/cedoc/responsabilidadesocial-empresarial-e-sustentabilidade-para-a-gestao-empresarial/.

Câmara, R. H. (2013). Análise de conteúdo: da teoria à prática em pesquisas sociais aplicadas as organizações. Revista Interinstitucional de Psicologia, 179191.

Cooper, D., \& Schindler, S. (2001). Métodos de pesquisa em administração. Bookman.

Córdula, A. (2020). Quarenta dias em suspensão. Castro, D.; Dal Seno, D.; Pochmann, M. (org.). Capitalismo e a Covid-19.

Costa, L. C. (2020). O Capitalismo e a Covid: um debate urgente. Abet.

Creswel, J. (2014). Investigação qualitativa e projeto de pesquisa: escolhendo entre cinco abordagens. Penso Editora.

Dalfovo, M. S., Lana, R., \& Silveira, R. (2008). Métodos quantitativos e qualitativos: um resgate teórico. Revista Interdisciplinar Científica Aplicada, 1-13.

Ethos. (2012). Instituto ethos. Manual de critérios essenciais de responsabilidade social e empresarial. https://www.ethos.org.br/wp-content/uploads/201 2/12/ 02_Manual-de-Incorpora\%C3\%A7\%C3\%A3o-dos-Crit\%C3\%A9rios-Essenciais-de-Responsabilidade-Social-Empre.

Ethos. (2019). Instituto ethos. https://www.ethos.org.br/obrigado-pelo-seu-interesse-em-baixar-um-de-nossos-documentos/?ver=8f93d8 9240364de5 b6976 cf1ba601647f532d468.

Friedman, M. (1984). Capitalismo e Liberdade. LTC.

Gife. (2007). Disponível em Grupo de Institutos, Fundações e Empresas: https://gife.org.br/who-we-are/?lang=en.

Gife. (2018). Disponível em Grupo de Institutos, Fundações e Empresas: https://gife.org.br/who-we-are/?lang=en.

Godoy, A. S. (1995). Introdução à pesquisa qualitativa e suas possibilidades. Revista de Administração de Empresas, 57-63.

Guédez, V. (2014). La Responsabilidad Social Empresarial em Perspectiva - Ideas para su Diseño, Implantación, Desarrollo y Evaluación. Caracas: Venancham.

Iso. (2010). Internacional Organization for Standardization - Iso 26000. https://www.iso.org/iso-26000-social-responsibility.html

Le figaro. (2020). https://www.rfi.fr/br/tag/le-figaro/.

Mainardi, C. I. (2020). Despertar pós-Covid-19. Em Castro, D., Dal Seno, \& M. (. POCHMANN, Capitalismo e a Covid-19. São Paulo.

Organização Pan-Americana de Saúde- Opas. (2020). https://www.paho.org/bra/index.php?option=com_content\&view=article\&id=6120:oms-afirma-quecovid-19-e-agora-caracterizada-como-pandemia\&Itemid=812.

Rodrigues, M. C. (2005). Ação social das empresas privadas: como avaliar resultados? FGV.

Sampieri, R. H., Collado, C. H., \& Lucio, P. B. (2003). Metodologia de pesquisa. Penso Editora.

Santos, B. S. (2020). A cruel pedagogia do vírus. São Paulo: Almedina. Edições Almedina: http://www.abennacional.org.br/site/wp-content/uploads/2020 /04/Livro_Boaventura.pdf.

Savitz, A. .. (2007). A empresa sustentavel : o verdadeiro sucesso é o lucro com responsabilidade social e ambiental. Elsevier.

Schommer, P. C. (2000). Investimento social das empresas: cooperação organizacional num espaço compartilhado. Organizações \& Sociedade, 7(19), 145160 .

Silva filho, O. J. (2018). Licença Social para Operar: importância dos elementos da gestão social nos projetos de Investimento Social Privado. Dissertação (Mestrado em Gestão Social, Educação e Desenvolvimento Local). - Programa de Pós-Graduação, Centro Universitário Uma, Belo Horizonte.

Silva, C. R., Gobbi, B. C., \& Simao, A. A. (2005). O uso da análise de conteúdo como uma ferramenta para a pesquisa qualitativa: Descrição e aplicação do método. Organizações Rurais Agroindustriais, 7(1), 70-81.

Silva, L., \& Dal bosco, M. (2020). Silva,L.S.B; Dal bosco,M.G. Garantia do direito a alimentação em época de pandemia no Brasil: um estudo comparativo entre as realidades perifericas durante as pandemias. Universidade Federal da Paraiba, em prelo, João Pessoa.

Snis. (2018). Serviço Nacional de Informações Sanitárias. Diagnóstico dos serviços de agua e esgotohttp://www.snis.gov.br/downl oads/diagnosticos/ae /2018/ Diagnostico_AE2018.pdf.

Sólio, M. B. (2013). Responsabilidade Social e sustentabilidade no contexto do século XXI. Revista Alceu, 13(26), 176-192.

Tenório, F. G. (2007). Responsabilidade social empresarial: Teoria e Prática (2 ed.). FGV. 